\title{
Economic Feasibility of Canola Production in the Region of Campos Gerais, Paraná, Brazil
}

\section{Eriton Luiz Mainardes, Luiz Cláudio Garcia*, Pedro Henrique Weirich Neto, Carlos Hugo Rocha, Thiago Inagaki, Natali Maidl de Souza, Guilherme Pedrollo Mazer, Jaime Alberti Gomes, Ivan Cesar Furmann Moura, Éverson Pedro Zeny}

State University of Ponta Grossa, Campus Uvaranas, Ponta Grossa, Brasil

Email: eriton.mainardes@gmail.com, *lcgarcia@uepg.br, lama1@uepg.br, chrocha@uepg.br, thiago811@yahoo.com.br, ivancesar.moura@gmail.com

How to cite this paper: Mainardes, E.L. Garcia, L.C., Weirich Neto, P.H., Rocha, C.H., Inagaki, T., de Souza, N.M., Mazer, G.P., Gomes, J.A., Moura, I.C.F. and Zeny, É.P. (2018) Economic Feasibility of Canola Production in the Region of Campos Gerais, Paraná, Brazil. American Journal of Plant Sciences, 9, 958-965.

https://doi.org/10.4236/ajps.2018.95073

Received: December 27, 2017

Accepted: April 15, 2018

Published: April 18, 2018

Copyright $\odot 2018$ by authors and Scientific Research Publishing Inc. This work is licensed under the Creative Commons Attribution International License (CC BY 4.0).

http://creativecommons.org/licenses/by/4.0/ (c) (i) Open Access

\begin{abstract}
This study aimed to analyze the economic feasibility of canola production (Brassica napus var oleifera) for the region Campos Gerais-PR. We interviewed eight producers, and used information from four of them for economic analysis of agricultural crops in 2012, 2013 and 2014. The variables analyzed were: grain production cost, economical analysis (hurdle rate, net present value, internal rate of return, payback, lucratively index, profitability index and sensitivity analysis) and vegetable oil production costs. We compared the performance of canola, wheat (Triticum aestivum) - as the main crop in the autumn/winter-and soybean (Glycine max) - by liquidity in the world market. It was concluded that although the economic analysis indicates superior results of canola production compared to the wheat crop and vegetable oil production is more attractive financially than soybean, but the culture of canola is still insignificant in the region of Campos Gerais (PR). The producers interviewed pointed to limit the expansion of culture financing the limited farming, production technology in consolidation, the need for machine adjustments and canola be host of the white mold disease (Sclerotinia sclerotiorun).
\end{abstract}

\section{Keywords}

Brassica napus, Production Systems, Profitability

\section{Introduction}

The canola (Brassica napus var. oleifera) is considered the third most important oilseed in the world. In Brazil, the area sown in the 2015 crop season was 53,610 ha. The national average income was $1352 \mathrm{~kg} \mathrm{ha}^{-1}$ in 2015 [1]. 
In Paraná State, the 2015 harvest reached 12.4 thousand tons. The average productivity in the state was $1525 \mathrm{~kg} \mathrm{ha}^{-1}$. The canola was commercialized at US $\$ 21.82$ per bag, generating profits of up to US\$ $311.65 \mathrm{ha}^{-1}$ [2].

The canola area in the regional nucleus of Ponta Grossa (PR) was 3075 ha in the 2014 crop season and 3500 ha in the agricultural year of 2015. For comparison purposes, wheat occupied 174,900 and 148,000 ha, respectively [3].

DERAL [4] emphasizes the low variety of pesticides registered for the crop; the inexpressive investment in technology and new cultivars the host plant of the fungal disease, are the main reasons for the low success of canola as a leader crop in the industrial sector. "White mold" (Sclerotinia sclerotiorum) - which also attacks soybean, is a state with high incidence of frost, uneven maturity of the plant, dehiscence of silica, adaptations in crop-specific agricultural machines.

The agency responsible for liberating the use of pesticides in Paraná State-the State Secretariat for Agriculture and Food Supply (SEAB)-lists 301 agrochemicals released for wheat, 560 for soybeans and only seven for canola [5].

In an economic analysis, Rodigherí [6] determined the Net Present Value (NPV) at US\$ 645.81 ha for soybean and wheat. In the same way, Pereira et al. [7] concluded that NPV for wheat was US\$ 44.50 for Paraná.

Studying agroforestry systems, Rodigherí [6] concluded that the Internal Rate of Return (IRR) was $8.96 \%$ for single soybeans and wheat in succession. The IRR was $7.86 \%$ for wheat cultivation in Paraná determined by Pereira et al. [7]. Based on the net cash flow, Amorim and Terra [8] in 60 hectares cultivated with soybeans determined the Payback Period of 2.5 years. In their research, Rodigherí [6] used the economic variable known as Profitability Index (IL) to indicate the value of 1.23 for single soybean and wheat crops in succession.

Using Sensitivity Analysis (AS) to compare crude margins and yield of canola hybrids, Zhang et al. [9] stated that changes of $\pm 10 \%$ in canola price in Australia shifts profit margin by $\pm 0.1 \mathrm{t} \mathrm{ha}^{-1}$. Working with AS in the cultivation of wheat in the state of Paraná, Pereira et al. [7] assure that the increase of $1.00 \%$ in the price caused an increase of $0.71 \%$ in the AS. In soybean crop in the state of Paraná, Melo et al. [10] applying AS with data from November 2005 to November 2011; emphasized that profitability is highly sensitive to price.

The oil content in canola grains varies from $40 \%$ to $48 \%$, while soybean-the main crop for biodiesel production in Brazil-ranges from $8.3 \%$ to $27.9 \%$. For this reason, the oil obtained from the canola crop has a higher economic return than other vegetable oils [11].

Due to the scarcity of financial studies for traditional crops in Brazil-such as wheat and soybeans-and especially for canola (almost inexistent), the objective of this study was to analyze the economic viability of canola production in the Campos Gerais-PR region.

\section{Material and Methods}

The research was concentrated in the region of Campos Gerais-PR. The produc- 
tion systems adopted for the present work are located in the cities of Reserva, Imbituva, Ponta Grossa and Teixeira Soares, respectively.

Initially, we performed structured interviews with eight farmers who have grown canola in recent years. From the preliminary data collection, we selected four canola production systems based in data consistency; denominated A, B, C and D for this study. The study period covered the crop seasons of 2012, 2013 and 2014.

The production systems adopted for the work have the following characteristics; the system A had an average area of $104 \mathrm{ha}^{-1}$, with an operational cost of around US\$ $168.23 \mathrm{ha}^{-1}$, achieving a productivity of $1700 \mathrm{~kg} \mathrm{ha}^{-1}$. System B, presented a cultivated area average of $69 \mathrm{ha}^{-1}$, with an operating cost of US\$221.05 $\mathrm{ha}^{-1}$ and a productivity of $1616.57 \mathrm{~kg} \mathrm{ha}^{-1}$. In system C, the average area cultivated was $48 \mathrm{ha}^{-1}$, with an operating cost of US\$239.66 at a yield of $1653.33 \mathrm{~kg}$ $\mathrm{ha}^{-1}$. In the D system, the averages presented for cultivated area were $68 \mathrm{ha}^{-1}$, with an operating cost of US\$177.38, achieving an average yield of $1520 \mathrm{~kg} \mathrm{ha}^{-1}$. Based on what was tabulated in the interviews, a table was developed to compare the four production systems.

In order to compare the economic positioning of the canola crop in the Campos Gerais (PR), the wheat crop (Triticum aestivum) was chosen since it is the main crop cultivated in the region during the period of canola production. Soybean (Glycine max) was also used once it is the crop with the highest liquidity in the world market.

The comparisons between the crops were performed by analyzes of investment and yield profitability, not taking into account the costs of land use in all analyzes. The economic values of wheat and soybean were obtained from the ABC Foundation, referring to the crop seasons of 2012, 2013 and 2014 [12].

The economic variables used were the Minimum Attractive Rate of Return (MARR), Net Present Value (NPV), Internal Rate of Return (IRR), Return Time of Investment (PAYBACK), Profitability Index (PI) and Profitability Index (VIR).

Long-term interest rate of the economy (MARR) of $6.75 \%$ per year was used as the minimum value to be considered in the economic viability evaluation of projects [13]. NPV was obtained by subtracting the initial investment from the present value of the net inflows (FCt), represented in the formula as $(-\mathrm{Co})$ discounted at a rate equal to the cost of capital of the company (r). In the NPV formula, $\left(V P L=-C o+\sum_{i}^{T} \frac{C i}{(1+r)^{i}}\right), C i$ is equal to the cash flow in the period, $i$, the time period analyzed. The Internal Rate of Return (IRR) was calculated as the interest rate that equates the Net Present Value (NPV) with the value of the project cost.

PAYBACK was obtained by the formula $\sum_{i=0}^{\infty} \frac{C i}{(1+r)^{i}} \geq$ and $\sum_{i=0}^{\infty-1} \frac{C i}{(1+r)^{i}} \leq 0$, where $\alpha$ is the life expectancy of the project, $i$ the time period analyzed, $C i$ as the 
cash flow in a given time period was the discount rate used.

With regard to the Profitability Index (PI), profitable investment was considered when the present value of net inflows exceeded the amounts invested. The formula employed was PI $=\frac{\mathrm{VE}}{\mathrm{VS}}$ where VE represented input values and VS output values.

To calculate the total costs, a $20 \%$ rate was added on the value of the project, considering the administrative costs, machinery and crop area depreciation [14].

The sensitivity analysis projected three scenarios: pessimistic, likely and optimistic. Thus, pessimistic scenarios of $-5 \%,-10 \%$ and $-15 \%$ of the value of canola were created, as in the $5 \%, 10 \%$ and $15 \%$ optimists; to verify in which even profitability would become attractive to the rural producer. The probable scenario was the profitability obtained in the average of the three canola agricultural crops (2012 to 2014).

The comparison of the production price of canola oil and soybean oil was also carried out; being removed cost values of raw materials [12] and costs of processing and sale of vegetable oil [15].

\section{Results and Discussion}

The tabulation of the responses of the eight interviews conducted with farmers who cultivated canola in the 2012, 2013 and 2014 crops in the Campos Gerais region (PR) highlighted the importance of canola in crop rotation for belonging to the crucifer family. Approximately $50 \%$ of the farmer properties work with canola for more than three years.

The characteristic of the properties that have cultivated canola in the region of Campos Gerais (PR) is over 300 ha; to be able to implement the high technology of production that the crop demands. However, the area devoted to canola cultivation by property was less than $60 \mathrm{ha}^{-1}$, with expansion below the expectation for technical issues mentioned by DERAL [4].

The subject of technical assistance, according to $62 \%$ of the interviewed producers, is one of the most significant obstacles. The reason given is that there is still no consolidated knowledge about the production system of the crop. As an example, few phytosanitary products were legally released for agronomic recommendations for the crop in Paraná [5].

Another limitation would be the lack of funding for the crop. Without investment resources for canola and with the technological contribution under construction, the farmer has chosen to produce based on fundraising and crops that dominates the productive process, such as wheat.

Private companies have been in charge of selling the seeds, providing technical assistance and intermediating the purchase of the production. Among the interviewees, $63 \%$ bought the seeds of resales and the rest in cooperatives. The cultivation in the region can be attributed to the actions of the private initiative; however, the said monopoly of the productive process is among the barriers of the expansion of canola in the region. 
Among the farmers interviewed, $86 \%$ emphasized the need to adapt machinery for operations in the canola crop. Seeding is challenging, but harvesting was the main issue reported. Only one of the producers interviewed did not change the machinery used to harvest the canola, using the same technology as the one used for the soybean crop.

White mold disease (Sclerotinia sclerotiorun) was mentioned as a limiting factor for the crop in the region of Campos Gerais (PR), as pointed out by DERAL [4]. In addition to the lack of technical assistance with crop specialization and the limited regulation and information on the inputs to the crop in the region, producers also reported problems in the transportation, processing and storage of canola.

One of the highlights of the interviews is that all producers already have a purchase link of the production determined before sowing, but with different forms and terms of negotiation in the contract.

The producers reported two main factors of motivation for insertion of the canola crop: the search for economic results (62\% of the answers) and the improvement of spring/summer crop productivity (38\% of respondents).

Comparing the data collected in the production systems of canola with those related to wheat and soybean - in the region of Campos Gerais (PR) - the annual investment analyzes were carried out (Table 1). It should be noted that the Minimum Attractive Rate of Return (MARR) was on average 31\% for canola, 33\% for wheat and $45 \%$ for soybean.

As the Net Present Value (NPV) takes into account the MARR, the values similar to canola and wheat are maintained; highlighting the results raised for soybeans. According to the review, Rodigherí (1997) showed NPV 2.75 times higher than the value presented in this study for wheat and 1.7 times for soybean. The wheat data highlighted in Table 1 is 5.3 times higher than those indicated by Pereira et al. [7]. The few data from the review on the subject presents a discrepancy due to economic conjuncture.

Table 1. Analyses of annual investment, with the average harvests in 2012, 2013 and 2014; comparing canola (Brassica napus var. oleifera), wheat (Triticum aestivum) and soybean (Glycine max) in four farms areas in the region of Campos Gerais (PR).

\begin{tabular}{cccccccc}
\hline Variables & Prop. 01 & Prop. 02 & Prop. 03 & Prop. 04 & $\begin{array}{c}\text { Average of } \\
\text { properties }\end{array}$ & Wheat & Soybean \\
\hline MARR (\%) & 35.2 & 27.0 & 28.1 & 33.3 & 31.0 & 33.4 & 45.1 \\
NPV (US\$ ha ${ }^{-1}$ ) & 171.1 & 221.9 & 228.1 & 181.5 & 202.3 & 234.6 & 378.9 \\
IRR (\%) & 27.3 & 15.3 & 18.0 & 28.0 & 22.2 & 25.6 & 57.7 \\
PAYBACK & 0.4 & 0.8 & 0.8 & 0.5 & 0.6 & 0.6 & 0.3 \\
PI & 1.5 & 1.2 & 1.4 & 1.6 & 1.5 & 1.5 & 2.1 \\
VIR & 0.7 & 0.4 & 0.4 & 0.8 & 0.6 & 0.5 & 1.0 \\
\hline
\end{tabular}

${ }^{*}$ MARR - Minimum Attractive Rate of Return, NPV—Net Present Value, IRR-Internal Rate of Return, PAYBACK-Payback Time, PI-Profitability Index and IR-Profitability Index. 
The Internal Rate of Return (IRR) shows numbers similar to canola in comparison to wheat. The soybean crop has more than double the crops worked. The IRR of the 2012 to 214 crops are at least 2.8 times larger than the figures presented by Rodigherí [6] for soybean and wheat. The $25 \%$ of wheat TIR in the Campos Gerais region (PR) is much higher than the $7.9 \%$ for wheat cultivation in Paraná determined by Pereira et al. [7].

The Payback period highlights the difference between the properties, with discrepant values of $100 \%$ in the canola crop. With 7.2 months, the capital invested in canola and wheat would be recovered. For soybeans 3.6 months would be sufficient for the return on investment. The values raised in this study are much lower than those determined by Amorim and Terra [8] for soybean crop; and the difference can be attributed to the non-computation of the cost of land use in the present study.

Comparing the Profitability Index (PI), the advantage of the soybean crop and the similar values for canola and wheat is highlighted. The Campos Gerais region presents higher numbers-in the 2012, 13 and 14 harvests-than those raised by Rodigherí [6] in the cultivation of single soybeans and wheat in succession.

Soybean yields almost double the Profitability Index (VIR) than wheat and canola, emphasizing that the crop does not compete directly in the same period as the other crops analyzed because it is one cultivated in the Campos Gerais $(\mathrm{PR})$ region in the period of spring/summer.

The sensitivity analysis (AS) for profitability (US\$ ha ${ }^{-1}$ ) highlights that canola was $28 \%$ higher than that of wheat in the crops and farms studied in the Campos Gerais region (PR). Soybean yield was 57\% higher than wheat and 23\% higher than canola (Table 2).

The AS with $\pm 10 \%$ in the canola price change in the region of Campos Gerais (PR) shifted the profit margin $\pm 0.16 \mathrm{t} \mathrm{ha}^{-1}$; Being the values more sensitive to the changes of price than those obtained by Zhang et al. [9] in Australia. In the present study, the increase of $1.00 \%$ in the price of wheat caused a $2.32 \%$

Table 2. Sensitivity analysis for profitability (US $\$ \mathrm{ha}^{-1}$ ), ranging from $15 \%$ to $15 \%$ in average selling prices of vintages 2012, 2013 and 2014; comparing canola (Brassica napus var oleifera), wheat (Triticum aestivum) and soybean (Glycine max) in four farms areas in the region of Campos Gerais (PR).

\begin{tabular}{cccccccc}
\hline & $-15 \%$ & $-10 \%$ & $-05 \%$ & 0 & $05 \%$ & $10 \%$ & $15 \%$ \\
\hline AREA 1 & 292.56 & 329.72 & 359.02 & 388.32 & 417.62 & 446.91 & 476.21 \\
AREA 2 & 215.66 & 243.71 & 271.45 & 299.19 & 327.24 & 354.97 & 383.02 \\
AREA 3 & 225.95 & 255.55 & 285.16 & 315.08 & 344.69 & 374.61 & 404.21 \\
AREA 4 & 260.54 & 288.28 & 315.70 & 343.13 & 370.56 & 398.29 & 425.72 \\
AVERAGE & 248.39 & 279.24 & 307.91 & 336.59 & 364.95 & 393.62 & 422.29 \\
WHEAT & 170.47 & 201.02 & 231.56 & 262.10 & 292.64 & 322.87 & 353.41 \\
SOYBEAN & 255.24 & 307.60 & 359.96 & 412.32 & 464.67 & 517.03 & 569.39 \\
\hline
\end{tabular}


Table 3. Comparison of production costs, sales value and profitability of canola (Brassica napus var oleifera) and soybean (Glycine max) in Brazil; of the years 2012, 2013 and 2014.

\begin{tabular}{ccccccc}
\hline \multirow{2}{*}{ Variables } & \multicolumn{3}{c}{ SOYBEAN } & \multicolumn{3}{c}{ CANOLA } \\
\cline { 2 - 7 } & 2012 & 2013 & 2014 & 2012 & 2013 & 2014 \\
\hline Total cost (US\$ t ${ }^{-1}$ ) & 440.43 & 445.66 & 453.05 & 473.71 & 484.01 & 504.88 \\
Revenues (US\$ t ${ }^{-1}$ ) & 612.69 & 674.59 & 966.90 & 1860.57 & 1861.01 & 2508.80 \\
Profitability (US\$ $\mathrm{t}^{-1}$ ) & 172.22 & 225.82 & 510.85 & 1386.50 & 1376.47 & 2003.93 \\
\hline
\end{tabular}

Source: ABIOVE [15].

increase in AS, a value higher than the $0.71 \%$ indicated by Pereira et al. [7] in Paraná. In the case of soybean, the data confirm that the profitability has great sensitivity to the price, as emphasized by Melo et al. [10].

The economic values presented highlighted the viability of canola cultivation in relation to wheat, and do not explain the difference of the cultivated area around 50 times greater of the cereal in the regional nucleus of Ponta Grossa (PR) [3]. The reduced area of canola in the region is linked to technical issues highlighted by the interviews.

Soybean production costs $8.2 \%$ lower than canola oil (Table 3). Counting the sales prices, we verified that the profitability of the canola in relation to the soybean was of eight, six and four times; Referring to the harvests of 2012, 2013 and 2014. The data corroborate with De Mori et al. [11] that the oil from the canola crop has an economic return superior to the other vegetable oils.

\section{Conclusions}

Although the economic analysis indicates higher yields of canola compared to wheat and its vegetable oil is more financially attractive than soybean, canola cultivation is still inexpressive in the Campos Gerais (PR) region.

The producers interviewed pointed out as restrictions to the expansion of the crop, the limited financing of agriculture, production technology in consolidation, need for adaptations in the machines and the fact that canola is a host of white mold disease (Sclerotinia sclerotiorun).

\section{References}

[1] EMBRAPA-Brazilian Agricultural Research Corporation (2014) Production Systems-Canola Cultivation. EMBRAPA, Passo Fundo.

https://www.spo.cnptia.embrapa.br/conteudo?p_p_id=conteudoportlet_WAR_siste masdeprodu-

caolf6_1ga1ceportlet\&p_p_lifecycle=0\&p_p_state $=$ normal\&p_p_mode $=$ view $\& p \_p$ col_id=column-1\&p_p_col_count=1\&p_r_p_-76293187_sistemaProducaoId=3703 \&p_r_p_-996514994_topicoId $=3024$

[2] CONAB-National Supply Company (2015) Follow-Up of the Brazilian Grain Crop. CONAB, Brasília.

https://www.conab.gov.br/index.php/info-agro/safras/graos/boletim-da-safra-de-gr aos?start $=30$ 
[3] SEAB/DERAL-Secretariat of Agriculture and Supply-PR/Department of Rural Economy (2016) Table of Agricultural Production by Municipality. SEAB/DERAL, Curitiba. http://www.agricultura.pr.gov.br/arquivos/File/deral/pss.xls

[4] DERAL—Department of Rural Economy (2015) Agricultural Production. DERAL, Brasília.

http://www.agricultura.pr.gov.br/modules/conteudo/conteudo.php?conteudo=137

[5] SEAB-Secretariat of Agriculture and Supply-PR (2015) Agrochemicals in Paraná. SEAB, Curitiba. http://celepar07web.pr.gov.br/agrotoxicos/pesquisar.asp

[6] Rodigherí, H.R. (1997) Comparative Economic Profitability between Forest Plantations and Agroforestry Systems with Yerba Mate, Eucalyptus and Pinus and the Crops of Beans, Corn, Soybeans and Wheat. EMBRAPA, Colombo. https://www.infoteca.cnptia.embrapa.br/bitstream/doc/290842/1/circtec26.pdf

[7] Pereira, M.W.G., Arêdes, A.F. and Teixeira, E.C. (2007) Economic evaluation of wheat cultivation in the States of Rio Grande do Sul and Paraná. Review Economy and Agribusiness, 5, 591-610.

[8] Amorim, F.R. and Terra, L.A.A. (2014) Economic Comparison between Sugarcane and Soybean Crop: The Case of a Supplier from the Region of Ribeirão Preto. Development and Management, 17, 322-333.

[9] Zhang, H., Berger, J.D., Seymour, M., Brill, R., Herrmann, C., Quinlan, R. and Knell, G. (2016) Relative Yield and Profit of Australian Hybrid Compared to Open Pollinated Canola Is Largely Determined by Growing Rainfall Season. Crop \& Pasture Science, 67, 41-49. https://doi.org/10.1071/CP15248

[10] Melo, C.O., Silva, G.H. and Esperancicni, M.S.T. (2012) Economic Analysis of Soybean and Corn Production in the Summer Harvest, in the State of Paraná. Agricultural Policy Review, 21, 121-132.

https://seer.sede.embrapa.br/index.php/RPA/article/view/78/64

[11] De Mori, C., Tomm, G.O. and Ferreira, P.E.P. (2014) Economic and Conjunctural Aspects of Canola Culture in the World and in Brazil. EMBRAPA, Passo Fundo. https://www.infoteca.cnptia.embrapa.br/infoteca/bitstream/doc/988475/1/2014docu mentosonline149.pdf

[12] ABC Foundation (2015) Production Costs. ABC Foundation, Castro. http://fundacaoabc.org.br

[13] Bank of Brazil (2016) Financial Services Agrobusiness. BANK OF BRAZIL, Brasília. http://bb.com.br/portalbb/page3,106,3125,10,1,1,2.bb

[14] Telles, S.V. and Salotti, B.M. (2015) Disclosure of Accounting Information on Depreciation: The before and after the Adoption of IFRS. Accounting Universe Review, 11, 153-173.

[15] ABIOVE-Brazilian Association of Vegetable Oils (2016) Installed Capacity of the Vegetable Oil Industry. ABIOVE, São Paulo.

http://www.abiove.org.br 